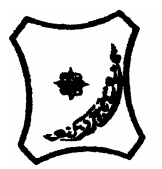

Bayero Journal of Pure and Applied Sciences, 4(2): $91-96$

Received: July, 2011

Accepted: October, 2011

ISSN $2006-6996$

\title{
C- REACTIVE PROTEIN IN TUBERCULOSIS AND HUMAN IMMUNODEFICIENCY VIRUS INFECTIONS IN ABEOKUTA, NIGERIA
}

\author{
${ }^{* D}$.A. Ojo, ${ }^{1}$ S. J. Jacob ${ }^{1}$ and C..I. Ayolabi ${ }^{2}$ \\ ${ }^{1}$ Department of Microbiology University of Agriculture, Abeokuta \\ ${ }^{2}$ Department of Botany and Microbiology University of Lagos, Lagos \\ *Correspondence author
}

\begin{abstract}
This study was conducted to evaluate C-reactive protein (CRP) levels in Mycobacterium tuberculosis and human immunodeficiency virus (HIV) infections and the follow-up therapeutic response to tuberculosis (TB) among patients aged 19-68 years attending out-patient clinics of two hospitals in Abeokuta, Southwestern Nigeria. Of 246 blood samples examined, the CRP value was highest (4.0\%) among age group 21-40 years and there was significant difference between CRP values of age groups $(p<0.001)$. More males $(4.6 \%)$ had higher CRP value than females $(1.5 \%)$, however there was no significant difference between their CRP values ( $p=0.173)$. C-reactive protein values was significantly higher $(30.8 \%)$ among patients with severe anaemia $(p<0.001)$. Also, the CRP value was significantly higher (57.1\%) among patients with elevated erythrocyte sedimentation rate value greater than $100 \mathrm{~mm} / \mathrm{h} \quad(p<0.001)$ and patients $(38.1 \%)$ with Mycobacterium tuberculosis infection $(p<0.001)$. C-reactive protein value was also significantly highest (50.0\%) among patients infected with HIV only and HIV patients co-infected with TB $(p<0.001)$. The elevated CRP values were progressively reduced to normal values $(0-10 \mathrm{mg} / \mathrm{L})$ among TB infected patients but not HIV co-infected patients within the eight weeks therapeutic period. In conclusion, CRP level in blood could be regarded as a sensitive indicator to monitor the response to chemotherapeutic treatments of Mycobacterium tuberculosis infection.
\end{abstract}

Keywords: C-reactive protein, Tuberculosis, Human Immunodeficiency, Virus, Outpatient, Abeokuta, Nigeria

\section{INTRODUCTION}

C-reactive protein (CRP) was first was discovered by Tillet and Francis in 1930, in patients infected with Streptococcus pneumoniae (Jaye and Waites, 2007). It appears to be produced by hepatocytes within 4-6 hours after onset of tissue injury or inflammation, doubling every 8 hours, before peaking at around 36 hours. Its half-life is short (4-8 hours) (Fraunberger et al., 2006).

CRP is an inflammatory marker whose concentration increases with acute or chronic inflammation. It is produced by the liver in response to stimulation by cytokines such as interleukin-1 beta, interleukin-6, and tumor necrosis factor alpha ( Nylen,et al., 2008). High-sensitivity measurement of CRP has been shown to add prognostic information at all levels of Framingham risk, ( Ridker et al., 2000) but CRP has not been consistently shown to be an independent risk factor across all studies ( Van der Meer et al., 2003). C-reactive protein (CRP) is an acute-phase protein and nonspecific marker of systemic inflammation (Black et al., 2004). The erythrocyte sedimentation rate (ESR) also provides a measure of inflammation, both elevated in the presence of inflammation, although, CRP response appears sooner than the rise in ESR. The CRP level falls to normal if treatment is successful but the ESR levels may still be abnormal for a longer period (Meisner et al., 2006).

Roughly, a one third of the world's population has been infected with M. tuberculosis, and new infections occur at a rate of one in every second (WHO, 2009). However, not all infections with $M$. tuberculosis cause disease and many infections are asymptomatic (Lambert et al., 2003). An estimated 13.7 million people had active TB disease, with 9.3 million new cases and 1.8 million deaths; the annual incidence rate varied from 363 per 100,000 in Africa to 32 per 100,000 in the Americas and the leading cause of death among people with HIV/AIDS (Sobero, 2006).

It is one of the most common AIDS-defining illnesses in Africa, despite the fact that treatment is available for it (Westreich et al., 2009). Active tuberculosis may boost HIV replication in vivo (Small et.al., 2003), and results of recent empirical studies show significant increases in mortality from tuberculosis in HIV infected individuals with advanced immunosuppression and in patients with acquired immunodeficiency syndrome (Goletti et al., 2006). Therefore, this study examines the C-reactive protein in tuberculosis and human immunodeficiency virus infections among hospital patients in Abeokuta with the possible clinical application of CRP assay in the diagnosis, treatment and monitoring of the infections.

\section{MATERIALS AND METHODS}

\section{Study Area}

The study was conducted in Abeokuta, Ogun State, Southwest Nigeria with a population of 593,140 of 2005 census (Dimeji, 2010). 
The study was carried out between June 2010 and November 2010 among patients of medical outpatients and in-patients unit of the Sacred Heart Hospital, Lantoro and State General Hospital, Ijaiye, Abeokuta. Ethical approval was obtained from each hospital ethical committee.

\section{Sample Collection}

A total of two hundred and seventy-one (271) sputum and blood samples(246 patients and 25control group subjects) were collected for this study. Each patient was made to produce about $10 \mathrm{ml}$ early morning sputum sample into a clean, sterile, wide-mouth container with fitting screw cap and stored at $4{ }^{\circ} \mathrm{C}$ until ready for analysis. Venous blood samples were obtained from each patient into ethylene diamine tetraacetate (EDTA) anticoagulated and nonanticoagulated tubes. The anticoagulated blood was used to determine PCV and ESR while the nonanticoagulated tube was centrifuged at 2000 revolution per minute (rpm) for 5 minutes to obtain serum for serologic assay.

\section{Microscopic Examination}

Sputum sample were pre-treated with $4 \%$ sodium hydroxide, concentrated by centrifugation, smear made from the sediment, heat fixed, stained by Ziehl-
Nelson's method and examined for acid fast bacilli(AFB).

\section{Human Immunodeficiency Virus (HIV) Test}

The HIV-1 and HIV-2 screening kits used in this study were Determinekit(Abbot Laboratory, USA) and Chembo HIV-1 $\backslash 2$, USA) as recommended by World Health Organization. These are immunochromatographic (rapid) methods for qualitative detection of antibodies of all isotypes (IgG, IgM, IgA) specific to HIV-1 and HIV-2 simultaneously in serum, plasma or whole blood. These methods used were highly sensitive, specific with very suitable control incorporated.

\section{C- reactive protein (CRP) Assay}

The CRP level was assayed using an immunoturbidimetric latex agglutination (Cypress Diagnostics, Belgium). This is an immunoturbidimetric assay. The CRP reagent was a suspension of positive latex particles coated with the gamma globulin fraction of anti human CRP specific serum. When CRP is present in the sample, the resulting turbidity was measured colorimetrically at $430 \mathrm{~nm}$. The CRP in each sample was calculated using a standard CRP solution. The normal CRP value for this assay is $0-10 \mathrm{mg} / \mathrm{L}$.

Calculations:

$$
\mathrm{CRP}_{\text {patient }}=\frac{\text { Patient Absorbance }}{\text { Standard Absorbance }} \quad \mathrm{X} \text { Concentration of Standard Solution }(20 \mathrm{mg} / \mathrm{L})
$$

\section{Haematocrit and Erythrocyte Sedimentation Rate Determination}

The haematocrit (Hct) which is also known as the packed cell volume (PCV) of each patient was determined by centrifugation of EDTA anticoagulated blood in capillary tubes (with one end sealed) using Hawskley haematocrit centrifuge. The erythrocyte sedimentation rate (ESR) of each patient was determined by Westergren-micro method using EDTA anticoagulated blood and the reading was taken at the end of one hour. The normal values for PCV and ESR are $34 \%-54 \%$ and $2-9 \mathrm{~mm} / \mathrm{hr}$ respectively.

\section{Statistical Analysis}

The study was carried out and the proportion of individual CRP levels was calculated. The CRP among the samples were cross tabulated with age, sex, packed cell volume, erythrocyte sedimentation rate, human immunodeficiency virus infection and tuberculosis infection using SPSS version 15. Relevant chi-square and significant values were computed using Pearson models.

\section{RESULTS}

Two hundred and forty-six patients were examined in this study as shown in Table 1 . There were more patients in the age group 21-40 years 176 (71.5\%) while fewer were seen in the 1-20 years age group $2(0.8 \%)$. The overall CRP value was highest among age group $21-40$ years $7(4.0 \%)$. The computed chisquare statistics for the test of no association between CRP values and age had a value of 45.476 and statistically significant at less than $1 \%$ level. Thus null hypothesis of no association is rejected.

The CRP value distribution by sex is shown in Table 2 . The patients comprised $109(44.3 \%)$ males and $137(55.7 \%)$ females aged $19-68$ years. Of the 246 patients examined, $219(89.0 \%)$ had CRP values of 0 $10 \mathrm{mg} / \mathrm{L}$ and $6(2.4 \%), 6(2.4 \%), 8(3.3 \%)$ and 7 $(2.8 \%)$ had respectively CRP values of $11-40 \mathrm{mg} / \mathrm{L}$, $41-$ $70 \mathrm{mg} / \mathrm{L}, 71-100 \mathrm{mg} / \mathrm{L}$ and greater than $100 \mathrm{mg} / \mathrm{L}$. The overall CRP value was highest $(>100 \mathrm{mg} / \mathrm{L})$ among male patients $5(4.6 \%)$. The computed chi-square statistics for the test of no association between the CRP values and sex in Table 2 had a value of 6.368 which is not significant at $1 \%$ level and thus null hypothesis of no association is accepted.

Table 3 showed that patients with severe anaemia (PCV <26\%) had highest CRP values $8(30.8 \%)$ than those with moderate anaemia $0(0 \%)$ and normal PCV $0(0 \%)$. The computed chi-square statistics for the test of no association between CRP values and anaemia had a value of 196.963 and significant at less than $1 \%$. Therefore the null hypothesis of no association is rejected.

The frequency distribution between the CRP and ESR in Table 4 showed that $6(2.9 \%)$ and $1(0.5 \%)$ of the patients with high CRP values of $11-40 \mathrm{mg} / \mathrm{L}$ and $71-$ $100 \mathrm{mg} / \mathrm{L}$ respectively had normal ESR $(2-9 \mathrm{~mm} / \mathrm{h})$ while $1(14.3 \%), 2(28.6 \%)$ and $4(57.1 \%)$ patients with elevated CRP values of $41-70 \mathrm{mg} / \mathrm{L}, 71-100 \mathrm{mg} / \mathrm{L}$ and greater than $100 \mathrm{mg} / \mathrm{L}$ had abnormal ESR (>100mm/h). 
The computed chi-square statistics for the test of no association between CRP and ESR levels had a value of 248.514 and is significant at less than $1 \%$ level. Thus the hypothesis of no association is rejected.

The cross tabulation between CRP and tuberculosis infection of patients examined in Table 5 shows that, of $21(8.5 \%)$ with Mycobacterium tuberculosis infections, $6(28.6 \%), 8(38.1 \%)$ and $7(33.3 \%)$ had elevated CRP values $41-70 \mathrm{mg} / \mathrm{L}, 71-100 \mathrm{mg} / \mathrm{L}$ and greater than $100 \mathrm{mg} / \mathrm{L}$ respectively. The chi-square status computed for the test of no association between CRP and Mycobacterium tuberculosis infections had a value of 246.000 and statistically significant at less than $1 \%$ level and therefore the null hypothesis of no association is rejected.

Table 6 shows the TB that coexists with HIV in relation to CRP among the patients examined. The overall prevalence of TB co-infection with HIV was 4 $(1.6 \%)$, of which $2(50 \%)$ and $2(50 \%)$ had respective elevated CRP values of $71-100 \mathrm{mg} / \mathrm{L}$ and greater than
$100 \mathrm{mg} / \mathrm{L}$. The chi-square status computed for the test of no association between CRP and TB co-infection with HIV had a value of 62.916 and statistically significant at less than $1 \%$ level. Thus rejection of the null hypothesis of no association.

It was observed that all the selected subjects for the control group were negative for Mycobacterium tuberculosis and HIV infections. Also, the C-reactive protein, packed cell volume and erythrocyte sedimentation rate values were within the normal values.

The frequency distribution of C-reactive protein and chemotherapeutic response of Mycobacterium tuberculosis and human immunodeficiency virus infections in Figure 1 showed that the elevated CRP values were progressively reduced to normal values $(0-10 \mathrm{mg} / \mathrm{L})$ among TB infected patients but not HIV co-infected patients within the eight weeks of therapeutic period.

Table 1: C - reactive protein Distribution by Age

\begin{tabular}{lllllll}
\hline Age (year) & $\begin{array}{l}\text { Total } \\
\text { Examined (n) }\end{array}$ & \multicolumn{5}{c}{ C-Reactive Protein (mg/L) } \\
\cline { 3 - 6 } & & $\begin{array}{l}\mathbf{0 - 1 0} \\
\mathbf{n}(\%)\end{array}$ & $\begin{array}{l}\mathbf{1 1 - 4 0} \\
\mathbf{n}(\%)\end{array}$ & $\begin{array}{l}\mathbf{4 1 - 7 0} \\
\mathbf{n}(\%)\end{array}$ & $\begin{array}{l}\mathbf{7 1 - 1 0 0} \\
\mathbf{n}(\%)\end{array}$ & $\begin{array}{l}\mathbf{7 1 0 0} \\
\mathbf{n}(\%)\end{array}$ \\
\hline $1-20$ & 2 & $0(0)$ & $0(0)$ & $1(50)$ & $0(0)$ & $1(50)$ \\
$21-40$ & 176 & $155(88.1)$ & $5(2.8)$ & $3(1.7)$ & $7(4.0)$ & $6(3.4)$ \\
$41-60$ & 62 & $59(95.2)$ & $1(1.6)$ & $1(1.6)$ & $1(1.6)$ & $0(0)$ \\
$>60$ & 6 & $5(83.3)$ & $0(0)$ & $1(16.7)$ & $0(0)$ & $0(0)$ \\
Total & 246 & $219(89.0)$ & $6(2.4)$ & $6(2.4)$ & $8(3.3)$ & $7(2.8)$ \\
\hline
\end{tabular}

Table 2: C - reactive protein Distribution by Sex

\begin{tabular}{|c|c|c|c|c|c|c|}
\hline \multirow[t]{2}{*}{ Sex } & \multirow{2}{*}{$\begin{array}{l}\text { Total } \\
\text { Examined (n) }\end{array}$} & \multicolumn{5}{|c|}{ C-Reactive Protein (mg/L) } \\
\hline & & $\begin{array}{l}0-10 \\
\mathrm{n}(\%)\end{array}$ & $\begin{array}{l}11-40 \\
\mathrm{n}(\%)\end{array}$ & $\begin{array}{l}41-70 \\
n(\%)\end{array}$ & $\begin{array}{l}71-100 \\
\mathrm{n}(\%)\end{array}$ & $\begin{array}{l}>100 \\
\mathrm{n}(\%)\end{array}$ \\
\hline Male & 109 & $97(89.0)$ & $4(3.7)$ & $1(0.9)$ & $2(1.8)$ & $5(4.6)$ \\
\hline Female & 137 & $122(89.1)$ & $2(1.5)$ & $5(3.6)$ & $6(4.4)$ & $2(1.5)$ \\
\hline Total & 246 & $219(89.0)$ & $6(2.4)$ & $6(2.4)$ & $8(3.3)$ & $7(2.8)$ \\
\hline
\end{tabular}

Table 3: Haematocrit Level in Relation to $\mathrm{C}$ - reactive protein

\begin{tabular}{|c|c|c|c|c|c|c|c|}
\hline \multirow[t]{2}{*}{ PCV (\%) } & \multirow[t]{2}{*}{$\begin{array}{c}\text { Total } \\
\text { Examined (n) }\end{array}$} & \multicolumn{4}{|c|}{ C-reactive protein (mg/L) } & \multicolumn{2}{|c|}{$\begin{array}{l}\text { Anaemia } \\
\text { Status }\end{array}$} \\
\hline & & $\begin{array}{l}0-10 \\
n(\%)\end{array}$ & $\begin{array}{l}11-40 \\
\mathrm{n}(\%)\end{array}$ & $\begin{array}{l}41-70 \\
\text { n (\%) }\end{array}$ & $\begin{array}{l}71-100 \\
n(\%)\end{array}$ & $\begin{array}{l}>\mathbf{1 0 0} \\
\mathrm{n}(\%)\end{array}$ & \\
\hline $34-54$ & 52 & $49(94.2)$ & $3(5.8)$ & $0(0)$ & $0(0)$ & $0(0)$ & Normal \\
\hline $26-34$ & 168 & $165(98.2)$ & $3(1.8)$ & $0(0)$ & $0(0)$ & $0(0)$ & Moderate \\
\hline$<26$ & 26 & $5(19.2)$ & $0(0)$ & $6(23.1)$ & $8(30.8)$ & $7(26.9)$ & Severe \\
\hline Total & 246 & $219(89.0)$ & $6(2.4)$ & $6(2.4)$ & $8(3.3)$ & $7(2.8)$ & \\
\hline
\end{tabular}

Table 4: Erythrocyte Sedimentation Rate in Relation to CRP Level.

ESR (mm/hr) Total Examined C-reactive protein (mg/L)

\begin{tabular}{ccccccc} 
& & $\begin{array}{l}\mathbf{0 - 1 0} \\
\mathbf{n}(\%)\end{array}$ & $\begin{array}{l}\mathbf{1 1 - 4 0} \\
\mathbf{n}(\%)\end{array}$ & $\begin{array}{l}\mathbf{4 1}-\mathbf{7 0} \\
\mathbf{n}(\%)\end{array}$ & $\begin{array}{l}\mathbf{7 1 - 1 0 0} \\
\mathbf{n}(\%)\end{array}$ & $\begin{array}{c}\mathbf{>} \mathbf{1 0 0} \\
\mathbf{n}(\%)\end{array}$ \\
\hline $2-9$ & 205 & $198(96.6)$ & $6(2.9)$ & $0(0)$ & $1(0.5)$ & $0(0)$ \\
$10-40$ & 23 & $21(91.3)$ & $0(0)$ & $1(4.3)$ & $0(0)$ & $1(4.3)$ \\
$41-70$ & 5 & $0(0)$ & $0(0)$ & $2(40.0)$ & $2(40.0)$ & $1(20.0)$ \\
$71-100$ & 6 & $0(0)$ & $0(0)$ & $2(33.3)$ & $3(50.0)$ & $1(16.7)$ \\
$>100$ & 7 & $0(0)$ & $0(0)$ & $1(14.3)$ & $2(28.6)$ & $4(57.1)$ \\
Total & 246 & $219(89.0)$ & $6(2.4)$ & $6(2.4)$ & $8(3.3)$ & $7(2.8)$ \\
\hline
\end{tabular}


Table 5: Tuberculosis Infection and $\mathrm{C}$ - reactive protein

TB Status Total Examined C-reactive protein (mg/L)

\begin{tabular}{|c|c|c|c|c|c|c|}
\hline & & $\begin{array}{l}0-10 \\
n(\%)\end{array}$ & $\begin{array}{l}11-40 \\
n(\%)\end{array}$ & $\begin{array}{l}41-70 \\
n(\%)\end{array}$ & $\begin{array}{l}71-100 \\
n(\%)\end{array}$ & $\begin{array}{l}>100 \\
\mathrm{n}(\%)\end{array}$ \\
\hline Negative & 225 & $219(97.3)$ & $6(2.7)$ & $0(0)$ & $0(0)$ & $0(0)$ \\
\hline Positive & 21 & $0(0)$ & $0(0)$ & $6(28.6)$ & $8(38.1)$ & $7(33.3)$ \\
\hline Total & 246 & $219(89.0)$ & $6(2.4)$ & $6(2.4)$ & $8(3.3)$ & $7(2.8)$ \\
\hline
\end{tabular}

Table 6: TB and HIV Co-infection in relation to $\mathrm{C}$ - reactive protein

\begin{tabular}{|c|c|c|c|c|c|c|}
\hline \multirow{2}{*}{$\begin{array}{l}\text { TB+HIV } \\
\text { Status }\end{array}$} & \multirow{2}{*}{$\begin{array}{l}\text { Total } \\
\text { Examined(n) }\end{array}$} & \multicolumn{5}{|c|}{ C-Reactive Protein (mg/L) } \\
\hline & & $\begin{array}{l}0-10 \\
\mathrm{n}(\%)\end{array}$ & $\begin{array}{l}11-40 \\
n(\%)\end{array}$ & $\begin{array}{l}41-70 \\
n(\%)\end{array}$ & $\begin{array}{l}71-100 \\
n(\%)\end{array}$ & $\begin{array}{l}>100 \\
\mathrm{n}(\%)\end{array}$ \\
\hline Negative & 242 & $219(90.5)$ & $6(2.5)$ & $6(2.5)$ & $6(2.5)$ & $5(2.1)$ \\
\hline Positive & 4 & $0(0)$ & $0(0)$ & $0(0)$ & $2(50)$ & $2(50)$ \\
\hline Total & 246 & $219(89.0)$ & $6(2.4)$ & $6(2.4)$ & $8(3.3)$ & $7(2.8)$ \\
\hline
\end{tabular}

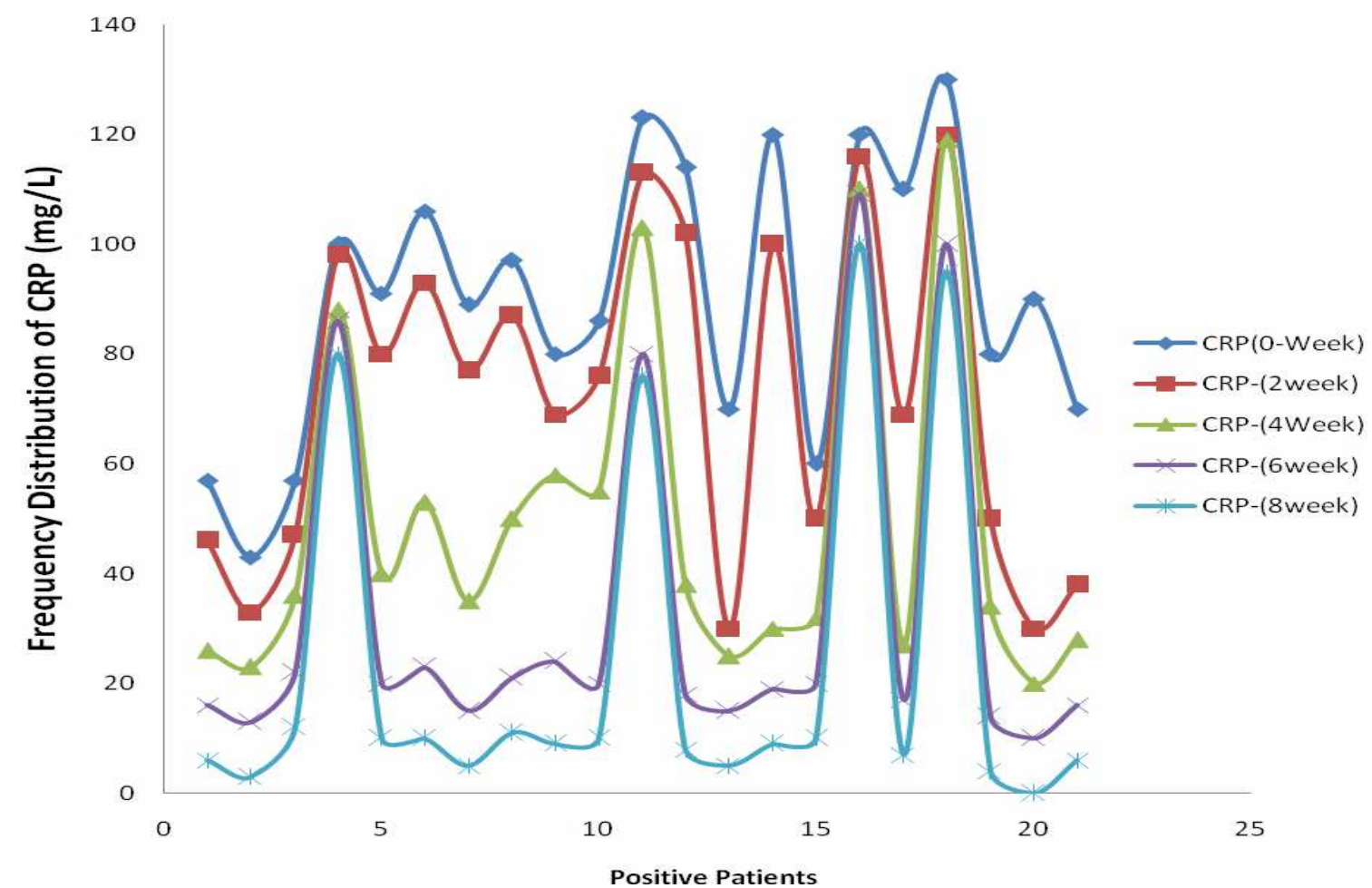

Figure 1: Frequency distribution of C-reactive protein and chemotherapeutic response of Mycobacterium tuberculosis and Human Immunodeficiency Virus (HIV) infections.

\section{DISCUSSION AND CONCLUSION}

The twin epidemics of TB and HIV place enormous strain on the limited healthcare resources in west-Africa (Howie et al., 2005). C-reactive protein levels have been studied as markers of bacterial lower respiratory tract infection in a number of populations and the results have so far been consistent (High et al., 2004). C-reactive protein (CRP) has a greater practical value than does the elevated sedimentation rate, and also since there is no borderline value in the sedimentation rate, the difference between normal and abnormal elevated sedimentation rate may be small, while the presence of CRP is an indication of pathology, and disappearance of CRP is concomitant with effectiveness of drugs which were used in treatment ( Nylen et al., 2008;).

This study showed that the CRP was highest in the age group 21-40 years among patients in Abeokuta metropolis. This report corresponds with previous reports (Cushman et al., 2009 and Zacho et al., 2009). This may be attributed to Tuberculosis (TB) diseases risk development in young adults (Marnell et al., 2005 and Cushman et al., 2009). This study is in contrast to the previous report by Ford et al (2004) that CRP levels increases with age. Previous investigation also recorded that young age is a risk factor for TB infection, for progression from infection to diseases and for spread of diseases to other parts of the body (Nachega, 2003; and WHO, 2007). 
Finally, previous investigation (Sobero, 2006; Kumar et al., 2007 and WHO, 2009) reported that 25\%-50\% of adolescents were infected with TB by the age 18 years and below. This may be due to the fact that adults are relatively immunosuppressed and their TB antibody levels are high (WHO, 2009).

There was no significant difference between sex and CRP, although more men had extremely elevated CRP values than women in this investigation which is in contrast to the previous report (Martin, 2006) of high prevalence of increased CRP levels in women than men. The differences may be due to socio-economic, geographical and ethnic groups in the study areas (Tso et al., 2004 and Cobat et al., 2010). Some studies reported that there is an increase in CRP levels in both men and women with TB infection (Lambert et al., 2003; Wilson, 2009; WHO, 2009; Selwyn et al., 2009 and Konstantinos, 2010). Many studies have been conducted that link CRP levels to other medical conditions, demographic, and socioeconomic factors (Lambert et al., 2003).

In the report of Kanfer and Pepys (2001) which is similar to the finding in this study, increased CRP was significantly observed in patients that had severe anaemia (PCV < 26\%). This observation is also supported by previous reports (Wetteland et al., 2006 and Zacho et al., 2009). Previous investigation (Thea et al., 2005 and Volanakis et al., 2009) also reported that TB patients with anaemia may be due to increase in age.

In this study, increased CRP values were observed in patients with extremely elevated erythrocyte sedimentation rate (ESR). Previous reports (Cook et al., 2006) are in support of this finding that the levels of ESR and CRP are useful indicators for inflammatory reactions.

The result of this study showed significant increase in the CRP levels of TB-positive patients which is in agreement with the previous investigations (Murphy et. al., 2005; Van den Broek et al., 2008 and Meintjes,

\section{REFERENCES}

Black, S., Kushner, I. and Samols, D. (2004). C-reactive protein. Journal of Biological Chemistry. 279: 48487-48490.

Cobat, A., Gallant, C.J. and Simkin, L. (2010). High heritability of antimycobacterial immunity in an area of hyperendemicity for tuberculosis disease. Journal of Infectious Diseases. 201 (1): 15-19.

Cook, N.R., Buring, J.E. and Ridker, P.M. (2006). The effect of including C-reactive protein in Tuberculosis risk prediction models for women. Journal of International Medicine. 145: 21-29.

Cushman, M., McClure, L.A., Howard, V.J., Jenny, N.S., Lakoski, S.G. and Howard, G. (2009). Implications of increased C-reactive protein for Tuberculosis risk stratification in black and white men and women in the United State. Clinical Chemistry. 55: 1627- 1636.

Dimeji, K.A. (2010). Water scarcity bites harder in Abeokuta. The Encyclopedia of Historic Places. (New York: Facts of File Publications). Page 2.

Fraunberger, P.Y., Wang, E., Holler, K.G., Parhofer, D., Nagel, A.K., Walli and Seidel, D. (2006). Prognostic value of interleukin 6 , procalcitonin and $\mathrm{C}$-reactive protein levels in intensive care unit patients during first increase of fever.
2010). Previous reports on TB-positive patients suggested that CRP is more likely to be elevated where more serious tissue damage has occurred in the lungs as a result of TB diseases (Wilson, 2009).

The findings in this study showed a significant increase in CRP level of TB/HIV co-infected patients which agrees with previous reports (Van den Broek et al., 2008; Meintjes et al., 2009a \& b ). This high level may be due to serious inflammation in TB among HIV-infected patients (Malkin et al., 2007 and Mark et al., 2007).

In this study, CRP values were elevated at presentation in all the TB infected patients and TB-HIV co-infected patients. The finding of an elevated CRP among TB infected patients and TB-HIV co-infected patients at presentation with an acute respiratory illness are consistent with observations from other studies (WHO, 2009). In the present study, higher CRP values were observed in TB patients with HIV- co-infection compared with patients with only pulmonary tuberculosis, which corroborate with previous studies (Jens et al., 2005 and Hsiao and Baker, 2005). In this study, the follow-up chemotherapeutic treatment shows that the elevated CRP values were progressively reduced to normal which indicate effective response to therapeutic treatment as observed in previous records (Hsioa and baker, 2005; Goletti et al., 2006 and Harries et.al., 2010).

Finally, it was established that CRP is of clinical significance in the follow-up and prognosis of TB, HIV and TB/HIV co-infection. All the patients with an acute pulmonary TB infection and TB-HIV co-infection had an elevated CRP while the CRP levels were progressively reduced to normal values in TB infected patients but not in HIV and TB/HIV co-infected patients after several weeks of chemotherapy. Therefore CRP levels in blood appear to be a sensitive indicator to monitor the response to chemotherapeutic treatments of Mycobacterium tuberculosis infection.

Journal of Acquired Immune Deficiency Syndrome. 26: 10-12.

Goletti, D., Weissman, D. and Jackson, R.W. (2006). Effect of Mycobacterium tuberculosis on HIV replication: role of immune activation. Journal of Immunology. 157:1271- 1278.

Harries, A.D., Taylor, K.M. and Sohail, M. (2010). The HIV-associated tuberculosis epidemic .when will we act? Journal of Clinical Epidemiology. 375(9729):1906-1919.

High, W.A., Evans, C.C. and Hoang, M.P. (2004). Cutaneous military tuberculosis in two patients with HIV infection. Journal of American Academic Dermatology. 50:1-5.

Howie, S., Voss, L., Baker, M., Calder, L., Gimwood, K. and Byrnes, C. (2005). Tuberculosis in New Zealand, 1992- 2001: a resurgence. Journal of Clinical Epidemiology. 90: 1157-61.

Hsiao, A.L. and Baker, M.D. (2005). Fever in the new millennium: A review of recent studies of markers of serious bacterial infection in febrile children. Current Opinion on Pediatric. 17: 5661.

Jaye, D.L. and Waites, K.B. (2007). Clinical applications of C-reactive protein in pediatrics. Current Opinion on Pediatric. 30:54- 58. 
Jens, G. H., Henrik, S., Jorn R. and Elisabeth, L. (2005). Predicting acute maxillary sinusitis in a general practice population. Scandinavian Journal of Infectious Diseases. 311 (6999): 233-236.

Kanfer, E.J. and Nicol, B.A. (1997). Haemoglobin concentration and erythrocyte sedimentation rate in primary care patients. Journal of the Royal Society of Medicine. 120 (1): 54-62.

Konstantinos, A. (2010). Testing for tuberculosis. Australian Prescriber. 33:12-18.

Kumar, V., Abbas, A.K., Fausto, N. and Mitchell, R. N. (2007). Robbins Basic Pathology (8th edition). Saunders Elsevier. pp. 516-522.

Lambert, M., Hasker, D., Roberfroid, B. and Vanderstuyft, C. (2003). Recurrence in tuberculosis: relapse or re-infection?. The Lancet Infectious Diseases. 3 (5): 282.

Mark, D.R., Langton, C. and Markowitz, J. (2007). Laboratory values for children with newly diagnosed inflammatory bowel disease. Pediatrics. 119 (6): 1113-9.

Malkin, J.E., Kranzer, K. and Wood, R (2007). Tuberculosis and human immunodeficiency virus infection in west Burkina Faso: clinical presentation and clinical evolution. Internal Journal of Tuberculosis. 1(1):68-74.

Marnell, L., Mold, C. and Du Clos, T.W. (2005). C-reactive protein: ligands, receptors and role in inflammation. Clinical Immunology. 117:104111.

Martin, C. (2006). Tuberculosis vaccines: past, present and future. Current Opinion on Pulmonary Medicine. 12 (3): 186-191.

Meintjes, G. (2010). Challenges in the clinical management of HIV-associated TB. $2^{\text {nd }}$ South African TB Conference, Durban.

Meintjes, G., Simon, A. and Partisani, M. (2009a). Randomized placebo-controlled trial of prednisone for the TB immune reconstitution inflammatory syndrome. Sixteenth Conference on Retrovirus and Opportunistic Infections, Montreal, abstract 34.

Meintjes, G., Simon, A. and Partisani, M. (2009b). Novel relationship between tuberculosis immune reconstitution inflammatory syndrome and antitubercular drug resistance. Journal of Clinical Infection. 48(5):667-676.

Meisner, M., Adina, H. and Schmidt, J. (2006). Correlation of procalcitonin and C- reactive protein to inflammation, complications and outcome during the intensive care unit course of multipletrauma patients. Journal of Biological Chemistry. 10: 1-10.

Murphy, C., Beckers, J. and Ruther, U. (2005). Regulation of the human C-reactive protein gene in transgenic mice. Journal of Biological Chemistry. 270: 704-708.

Nylen, E.S., Whang, K.T., Snider, R.H., Steinwald, P.M., White, J.C. and Becker, K.L. (2008). Mortality is increased by procalcitonin and decreased by an antiserum reactive to procalcitonin in experimental sepsis. Critical Care Medicine. 26: 1001-1006.

Pepys, M.B. (2001). C-reactive protein. Fifty years on. Journal of Pediatric Infection. 1:653-657.

Ridker, P.M., Hennekens, C.H., Buring, J.E. and Rifai, N. (2000). C-reactive protein and other markers of inflammation in the prediction of cardiovascular disease in women. Journal of Clinical Medicine. 342:836-843.

Selwyn, P.A., Hartel, D. and Lewis, V.A. (2009). A prospective study of the risk of tuberculosis among intravenous drug users with human immunodeficiency virus infection. Journal of Clinical Medicine. 320:545-550.

Small, P.M., Shafer, R.W. and Hopewell, P.C. (2003). Exogenous re-infection with multidrug resistant Mycobacterium tuberculosis in patients with advanced HIV infection. Journal of Clinical Infection. 328:1137-1144.

Sobero, R. (2006). Tuberculosis control in Bolivia, Chile, Colombia and Peru: why does incidence vary so much between neighbors? Journal of Tubercle Lung Diseases. 10 (11): 1292-1295.

Thea, H., Marti, K.L. and Korrie, K. (2005). Impact of AIDS on rural livelihood in Benue State, Nigeria. Journal of Social Aspect of HIV/AIDS. Research Alliance. 3: 3-6.

Tso, H.W., Lau, Y.L., Tam, C.M., Wong, H.S. and Chiang, K.S. (2004). Associations between IL12B polymorphisms and tuberculosis in the Hong Kong Chinese population. Journal of Infectious Diseases. 190 (5): 913-919.

Van den Broek, J., Arpaia, G. and Ciliberto, G. (2008). Impact of human immunodeficiency virus infection on the outcome of treatment and survival of tuberculosis patients in Mwanza, Tanzania. Internal Journal of Tuberculosis. 2(7):547-52.

Van der Meer, I.M., De Maat, M.P., Kiliaan, A.J, Van der Kuip, D.A., Hofman, A. and Witteman J.C. (2003). The value of C-reactive protein in cardiovascular risk prediction: the Rotterdam Study. Journal of Internal Medicine. 163:13231328.

Volanakis, J.E. Kaplan, M.H. and Wirtz, K.W.A. (2009). Interaction of $\mathrm{C}$-reactive protein with artificial phosphatidylcholine bilayers. Journal of Internal Medicine.281, 155-157.

Westreich, D., Koes, B.W. and Van Eijk, J.T.M. (2009). Tuberculosis treatment and risk of stavudine substitution in first-line antiretroviral therapy. Journal of Clinical Infection. 48:109-120.

Wetteland, P., Roger, M., Solberg, H.E. and Iversen, O.H. (2006). Population-based erythrocyte sedimentation rates in 3910 subjectively healthy Norwegian adults. A statistical study Sbased on men and women from the Oslo area. Journal of Internal Medicine. 240 (3): 125- 131.

World Health Organization (2009). Epidemiology. Global tuberculosis control: Epidemiology, Strategy and Financing. pp. 6-33.

Wilson, D. (2009). Performance of C-reactive protein as screening tool for smear negative Pulmonary Tuberculosis in HIV-positive adults. Fourth South-African Aids conference, Durban, South Africa. Abstract. Page 413.

Zacho, J., Jensen, J.S., Grande, P. and Sillesen, H. (2009). Gentrically elevated C-reactive protein and systemic vascular diseases. New England Journal of Medicine. 359: 1897- 1908. 